\title{
METAMORPHIC EVOLUTION OF GARNET-BIOTITE-MUSCOVITE SCHIST FROM BARRU COMPLEX IN SOUTH SULAWESI, INDONESIA
}

\author{
Nugroho Imam Setiawan ${ }^{* 1}$, Yasuhito Osanai ${ }^{2}$, Nobuhiko Nakano $^{2}$, and Tatsuro Adachi ${ }^{2}$ \\ ${ }^{1}$ Geological Engineering Department, Faculty of Engineering, Universitas Gadjah Mada, Yogyakarta, Indonesia. \\ ${ }^{2}$ Division of Earth Sciences, Faculty of Social and Cultural Studies, Kyushu University, Fukuoka, Japan.
}

\begin{abstract}
This paper explains the first report in metamorphic evolution of pelitic schist from Barru Complex in South Sulawesi, Indonesia. Garnet-biotitemuscovite schist was examined petrologically to assess the metamorphic evolution history, which has implications on tectonic condition of this region. The rock mainly composed of garnet, biotite, muscovite, epidote, quartz, rutile, hematite, and plagioclase. Inclusions in the garnet preserve records of prograde stage of this rock, which are epidote, titanite, quartz, and apatite. Garnet, biotite, muscovite, quartz, rutile, and plagioclase are concluded as equilibrium assemblages at peak $P-T$ condition of this rock, which estimated at 501-562 ${ }^{\circ} \mathrm{C}$ and $0.89-0.97 \mathrm{GPa}$. The result is still on the ranges of the estimated geothermal gradient P-T path of eclogite from Bantimala Complex. Similar geothermal gradients of metamorphisms might be indicated that these metamorphic rocks were metamorphosed on the similar tectonic environments.
\end{abstract}

Keywords: Pelitic schist, Barru Complex, South Sulawesi, metamorphic evolution.

${ }^{*}$ Corresponding author: N.I. SETIAWAN, Geological Engineering Department, Faculty of Engineering Universitas Gadjah Mada. Jl. Grafika No. 2, Bulaksumur, Yogyakarta 55281, Yogyakarta, Indonesia. E-mail: nugroho.setiawan@ugm.ac.id

\section{Introduction}

Accretionary units and regional metamorphic rocks crop out in South Sulawesi. Those are exposed in restricted area namely Bantimala and Barru Complexes. Bantimala Complex is well-known to be worldwide outcrop of high-pressure and ultra-high pressure metamorphic rocks (eclogite, blueschist; Sukamto, 1982; Wakita et al., 1994a, 1996; Miyazaki et al., 1996; Parkinson et al., 1998; Setiawan, 2013). Whereas $30 \mathrm{~km}$ north of this complex, lowto medium-grade metamorphic rocks expose in more restricted area namely as Barru Complex. However, there were lacks of publications about metamorphic rocks from Barru Complex in particularly their metamorphic evolution.

This paper explains the occurrence of garnetbiotite-muscovite schist from Barru Complex. Detailed assessment of chemical zonation and inclusion texture of euhedral garnet and associated minerals are well correlated to the metamorphic evolution history. Furthermore, the manuscript attempts to interpret the tectonic implications of this metamorphic rock in comparison with other terranes in South Sulawesi. Mineral abbreviation in this paper follows Whitney and Evans (2010).

\section{Geological outline}

Cretaceous subduction complexes, which are represented by the occurrence of accretionary 
units such mélanges, pillow basalts, dismembered ophiolites, cherts, serpentinites, highpressure metamorphic rocks, and occanionally granulites and garnet lherzolites are sporadically exposed in central Indonesia region through Java, Kalimantan, and Sulawesi Islands (Sukamto, 1982; Wakita et al., 1994a, 1994b, 1996, 1998; Miyazaki et al., 1996, 1998; Parkinson, 1998a, 1998b; Wilson and Moss, 1999, Kadarusman and Parkinson, 2000; Kadarusman et al., 2005). The distribution of the accretionary units and metamorphic rocks are shown in Figure 1a. Most of the metamorphic rocks exposing in the complexes occur in a limited areas and is bounded by the thrust fault with other units such as dismembered ophiolites, cherts, mélanges, and serpentinites (Sukamto, 1982; Asikin et al., 2007; Sikumbang and Heryanto, 2009). In the South Sulawesi, the metamorphic rocks crop out in the restricted area namely as Bantimala and Barru Complexes (Figure 1b). The Bantimala Complex in South Sulawesi has significantly important meaning for one of the famous high-pressure metamorphic terranes in the world. Furthermore, Parkinson et al., (1998) reported ultra-high pressure metamorphic rocks, which is garnet-jadeite-quartz rock that experienced peak metamorphism at $>2.7$ GPa on $720-760^{\circ} \mathrm{C}$ from this complex.

The Barru Complex is located approximately $70 \mathrm{~km}$ northeast of the Makassar (Figure 1p). Metamorphic rocks in this area are bounded in the north with ultramafic rocks and in the south with Late Cretaceous sedimentary rocks (Figure 1). The most common lithologies in this area are variably of garnetiferous quartz-mica schist and serpentinized peridotite. Most of the metamorphic rocks crop out along the Dengedenge River (Figure 1/k). Reliable P-T condition of the metamorphic rocks in this area has not been reported previously. Wakita et al. (1994a) reported the phengite K-Ar age of the quartz-mica schist to be $106 \pm 5 \mathrm{Ma}$, which interpreted as exhumation ages.

\section{Occurrence and sample descriptions}

The exposures of the metamorphic rocks in the Barru Complex are well preserved along the
Dengedenge River (Figure $1 k$ ). The foliation of garnet-biotite-muscovite schist varies from $\mathrm{N}$ $80^{\circ} \mathrm{E}$ to $\mathrm{N} 30^{\circ} \mathrm{E}$ with dipping $30^{\circ}$ to $60^{\circ}$ to the east (Figure 2). Petrographical and mineral chemistry analyses were done on the garnetbiotite-muscovite schist with sample number 031202A. Mineral chemistries were analyzed with a JEOL JXA-8530F hyperprobe EPMA and a JEOL JED2140-JSM5301S scanning electron microscope with energy dispersive spectrometry system (SEM-EDS) in Kyushu University, Japan. The analytical conditios of EPMA was set an accelerating voltage of $15 \mathrm{kV}$, a probe current of $12 \mathrm{nA}$ and a beam diameter of $2 \mu \mathrm{m}$. The analytical conditions of SEM-EDS JED2140JSM5301S was set at an accelerating voltage of $15 \mathrm{kV}$, a probe current of ca. $0.35 \mathrm{nA}$, and a beam diameter of $1 \mu \mathrm{m}$. Natural mineral samples (ASTIMEX-MINM-53) and synthesized oxide samples (P and H Block No. SP00076) were used as standards for the quantitative chemical analyses. $\mathrm{Fe}^{3+}$ contents of garnet and plagioclase were calculated using algorithms proposed by Droop (1987). Micas formulae have been calculated to eleven oxygen atoms assuming all iron to be $\mathrm{Fe}^{2+}$. Cation formulae of epidote and titanite have been calculated assuming all iron to be $\mathrm{Fe}^{3+}$. Representative chemical compositions of the analyzed minerals are listed Table1.

The garnet-biotite-muscovite schists are mainly composed of garnet, biotite, muscovite, epidote, quartz, rutile, hematite, and plagioclase. The schistosity is defined by alignments of muscovite and biotite (Figures $3 \mathrm{a}-\mathrm{b}$ ). Garnet porphyroblasts $\left(\sim 0.3 \mathrm{~mm}\right.$ in diameter; $\operatorname{Prp}_{2-6}$, $\left.\mathrm{Alm}_{61-69}, \mathrm{Sps}_{1-8}, \mathrm{Grs}_{24-30}\right)$ have inclusions of quartz, titanite, apatite, and epidote $\left[\mathrm{X}_{\mathrm{Fe}^{3+}}=\right.$ $\left.\mathrm{Fe}^{3+} /\left(\mathrm{Fe}^{3+}+\mathrm{Al}\right)=0.13-0.22\right]$ (Figures 3c-d). Garnet has wide core and mantle of spessartine rich relative to almandine $\left(\operatorname{Prp}_{2-4}, \mathrm{Alm}_{61-67}\right.$, $\mathrm{Sps}_{5-8}, \mathrm{Grs}_{27-33}$ ) (Figures $4 \mathrm{a}-\mathrm{b}$ ). Whereas the rim portion is characterized by slightly rich of pyrope and almandine, relative to spessartine (Prp $\left.4-7, \mathrm{Alm}_{63-69}, \mathrm{Sps}_{0-3}, \mathrm{Grs}_{24-33}\right)$ (Figure 4b). Grossular content is constant from core to rim (Figure $4 \mathrm{~b}$ ). The garnet forms augen shape surrounded by sheaf texture of biotite $\left(0.1-0.5 \mathrm{~mm} ; X_{\mathrm{Mg}}=0.47-0.55, X_{\mathrm{Si}}=0.59-0.63\right)$ 

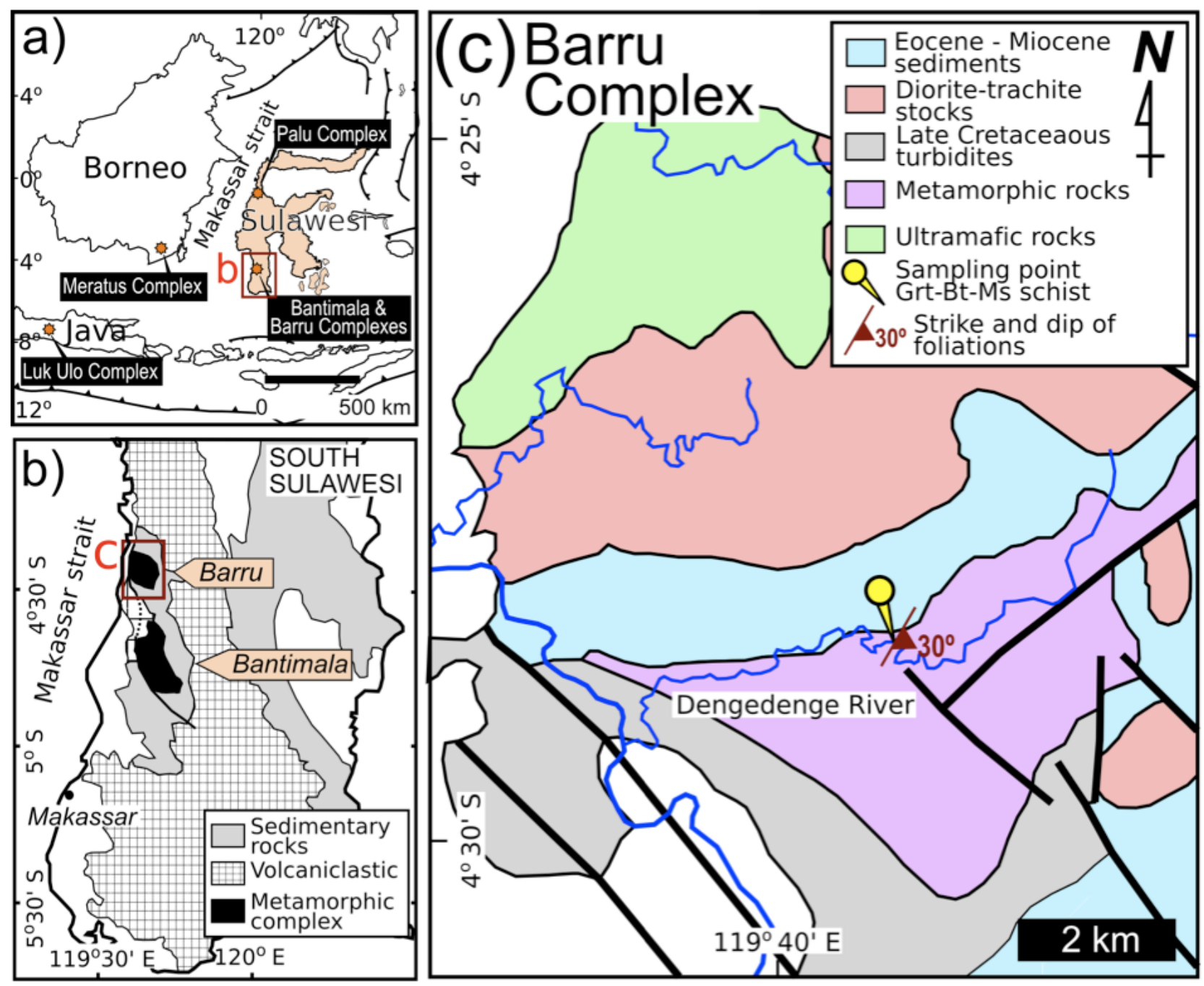

Figure 1: (a) Distribution of high-pressure metamorphic rocks related to the Cretaceous subduction complex in central Indonesia. (b) Location and (c) simplified geological map of the Barru Complex in South Sulawesi (modified after Sukamto, 1982) with sampling location. 
Table 1: Representative microprobe analyses of garnet, biotite, muscovite, and plagioclase in garnet-biotite-muscovite schist from Barru Complex.

\begin{tabular}{|c|c|c|c|c|c|c|c|c|c|}
\hline \multirow[t]{2}{*}{ Mineral } & \multicolumn{3}{|c|}{ Grt } & \multicolumn{2}{|c|}{$\mathrm{Bt}$} & \multicolumn{2}{|c|}{ Ms } & \multicolumn{2}{|c|}{ Pl } \\
\hline & core & mantle & $\operatorname{rim}^{\ddagger}$ & matrix ${ }^{\ddagger}$ & matrix & matrix $\ddagger$ & matrix & matrix $\neq$ & matrix \\
\hline $\mathrm{SiO}_{2}$ & 38.19 & 38.35 & 38.55 & 37.07 & 38.17 & 47.49 & 47.53 & 59.20 & 62.27 \\
\hline $\mathrm{TiO}_{2}$ & 0.01 & 0.23 & 0.00 & 1.44 & 1.08 & 0.48 & 0.38 & 0.12 & 0.19 \\
\hline $\mathrm{Al}_{2} \mathrm{O}_{3}$ & 21.18 & 21.38 & 21.18 & 20.59 & 20.98 & 34.57 & 33.61 & 25.02 & 23.28 \\
\hline $\mathrm{Cr}_{2} \mathrm{O}_{3}$ & 0.00 & 0.00 & 0.00 & 0.00 & 0.19 & 0.02 & 0.00 & 0.02 & 0.00 \\
\hline $\mathrm{FeO}$ & 27.17 & 27.06 & 27.36 & 17.25 & 16.19 & 0.80 & 1.80 & 0.00 & 0.00 \\
\hline $\mathrm{Fe}_{2} \mathrm{O}_{3}$ & - & - & - & - & - & - & - & - & - \\
\hline $\mathrm{MnO}$ & 3.50 & 3.14 & 0.14 & 0.13 & 0.00 & 0.05 & 0.00 & 0.12 & 0.05 \\
\hline $\mathrm{MgO}$ & 0.80 & 0.59 & 1.60 & 10.40 & 9.19 & 0.62 & 1.19 & 0.07 & 0.00 \\
\hline $\mathrm{CaO}$ & 9.50 & 9.53 & 11.60 & 0.23 & 0.00 & 0.00 & 0.00 & 6.11 & 5.63 \\
\hline $\mathrm{Na}_{2} \mathrm{O}$ & 0.00 & 0.01 & 0.01 & 0.08 & 0.30 & 0.58 & 1.21 & 9.26 & 8.93 \\
\hline $\mathrm{K}_{2} \mathrm{O}$ & 0.00 & 0.00 & 0.13 & 7.21 & 9.03 & 10.19 & 9.33 & 0.25 & 0.01 \\
\hline Total & 100.35 & 100.29 & 100.57 & 94.40 & 95.13 & 94.80 & 95.05 & 100.17 & 100.36 \\
\hline $\mathrm{O}$ & 12 & 12 & 12 & 11 & 11 & 11 & 11 & 8 & 8 \\
\hline $\mathrm{Si}$ & 3.04 & 3.04 & 3.03 & 2.76 & 2.83 & 3.16 & 3.16 & 2.65 & 2.76 \\
\hline $\mathrm{Ti}$ & 0.00 & 0.01 & 0.00 & 0.08 & 0.06 & 0.02 & 0.02 & 0.00 & 0.01 \\
\hline $\mathrm{Al}$ & 1.99 & 2.00 & 1.96 & 1.81 & 1.83 & 2.71 & 2.63 & 1.32 & 1.21 \\
\hline $\mathrm{Cr}$ & 0.00 & 0.00 & 0.00 & 0.00 & 0.01 & 0.00 & 0.00 & 0.00 & 0.00 \\
\hline $\mathrm{Fe}$ & 1.81 & 1.80 & 1.80 & 1.07 & 1.00 & 0.04 & 0.10 & 0.00 & 0.00 \\
\hline $\mathrm{Mn}$ & 0.24 & 0.21 & 0.01 & 0.01 & 0.00 & 0.00 & 0.00 & 0.00 & 0.00 \\
\hline $\mathrm{Mg}$ & 0.09 & 0.07 & 0.19 & 1.15 & 1.01 & 0.06 & 0.12 & 0.00 & 0.00 \\
\hline $\mathrm{Ca}$ & 0.81 & 0.81 & 0.98 & 0.02 & 0.00 & 0.00 & 0.00 & 0.29 & 0.27 \\
\hline $\mathrm{Na}$ & 0.00 & 0.00 & 0.00 & 0.01 & 0.04 & 0.07 & 0.16 & 0.80 & 0.77 \\
\hline K & 0.00 & 0.00 & 0.01 & 0.69 & 0.85 & 0.86 & 0.79 & 0.01 & 0.00 \\
\hline Total cation & 7.97 & 7.94 & 7.99 & 7.60 & 7.64 & 6.94 & 6.98 & 5.09 & 5.01 \\
\hline $\mathrm{Fe}^{3+}$ & - & - & - & - & - & - & - & - & - \\
\hline $\mathrm{Fe}^{2+}$ & 1.81 & 1.80 & 1.80 & 1.07 & 1.00 & 0.04 & 0.10 & 0.00 & 0.00 \\
\hline $\operatorname{Prp}(\%)$ & 3.22 & 2.42 & 6.31 & - & - & - & - & - & - \\
\hline Alm (\%) & 61.32 & 62.20 & 60.51 & - & - & - & - & - & - \\
\hline Sps (\%) & 8.00 & 7.31 & 0.31 & - & - & - & - & - & - \\
\hline Grs (\%) & 27.47 & 28.07 & 32.87 & - & - & - & - & - & - \\
\hline An (\%) & - & - & - & - & - & - & - & 26.38 & 25.82 \\
\hline $\mathrm{Ab}(\%)$ & - & - & - & - & - & - & - & 72.34 & 74.12 \\
\hline Or (\%) & - & - & - & - & - & - & - & 1.28 & 0.05 \\
\hline $\mathrm{Fe}^{2+} /\left(\mathrm{Fe}^{2+}+\mathrm{Mg}\right)$ & 0.95 & 0.96 & 0.91 & - & - & - & - & - & - \\
\hline $\mathrm{Si} /(\mathrm{Si}+\mathrm{Al})$ & - & - & - & 0.60 & 0.61 & 0.54 & 0.55 & - & - \\
\hline $\mathrm{Fe}^{3+} /\left(\mathrm{Fe}^{3+}+\mathrm{Al}\right)$ & - & - & - & - & - & - & - & - & - \\
\hline
\end{tabular}




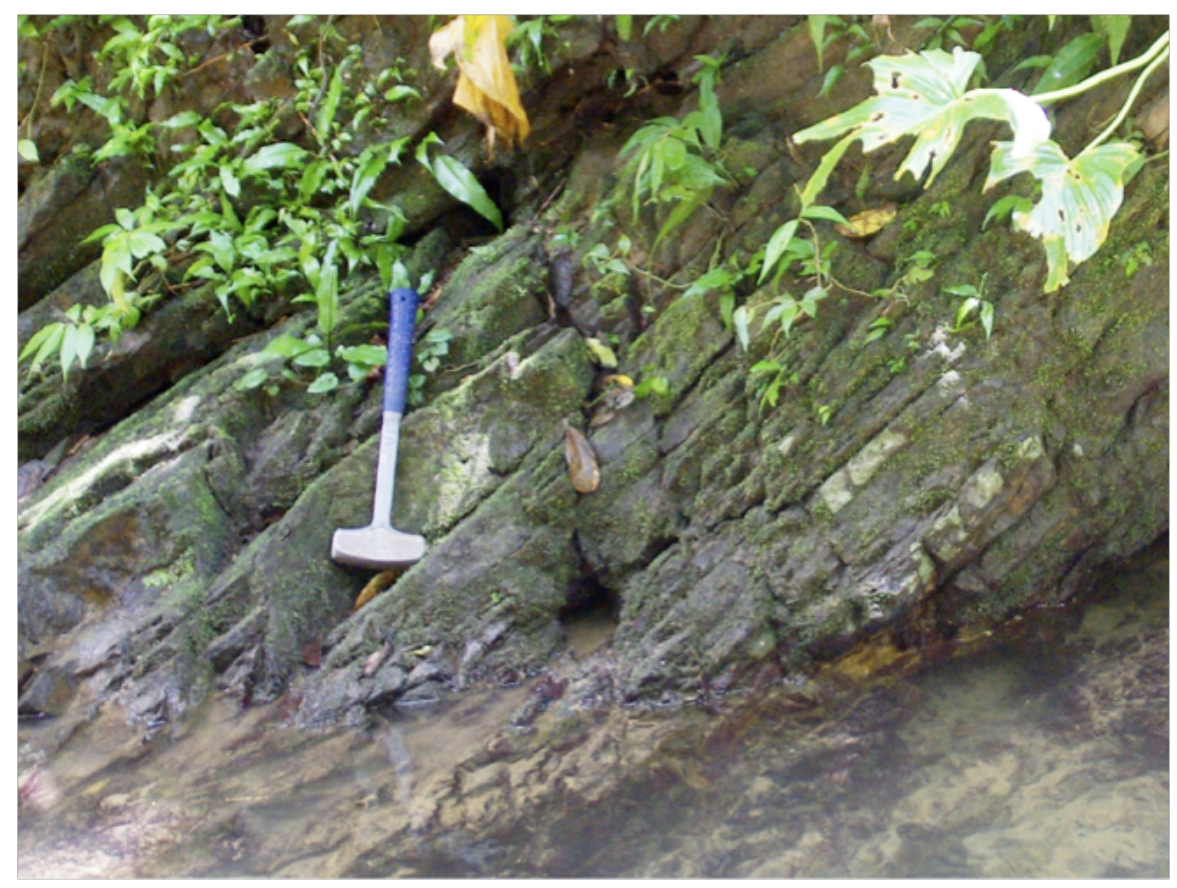

Figure 2: Mode of occurences garnet-biotite-muscovite schist in Dengedenge River of Barru Complex, South Sulawesi.

and muscovite $\left(0.1-0.5 \mathrm{~mm} ; X_{\mathrm{Mg}}=0.52-0.67\right.$, $\left.X_{\mathrm{Si}}=0.53-0.61\right)$ (Figure $4 \mathrm{c}$ ). Microcrystalline quartz occurs as pressure shadow adjacent to the garnet (Figure $3 \mathrm{a})$. Plagioclase $(0.2-0.7 \mathrm{~mm}$ in diameter; $\mathrm{An}_{14-26} \mathrm{Ab}_{72-85}$ ) forms abundant porphyroblasts in this schist (Figure 4d). Rutile $(<0.1 \mathrm{~mm})$, which present in the matrix, is commonly rimmed by titanite. Secondary chlorite $\left[\mathrm{Fe}^{2+} /\left(\mathrm{Fe}^{2+}+\mathrm{Mg}\right)=0.47-0.53\right]$ commonly replaces garnet porphyroblasts, micas, and other minerals (Figure 3b). Calcite and albite $\left(X_{\mathrm{Ab}}=\right.$ 0.99-1.00; Figure 4d) occur as interstitial. The petrography and mineral chemistry analyses result of mineral assemblages in garnet-biotitemuscovite schist is summarized in Table 2 .

\section{Metamorphic evolution}

The metamorphic evolution of garnet-biotitemuscovite schist from Barru Complex is estimated based on the mineral coexistence from the petrographical observation. Inclusions in the garnet preserve records of prograde stage of this rock, which are epidote, titanite, quartz and apatite. However, it is lack of mineral parageneses in the prograde stage to constraint the pressure-temperature condition. Hence, only peak metamorphic condition could be estimated from this rock. Garnet, biotite, muscovite, quartz, rutile, and plagioclase are concluded as equilibrium assemblages at peak $P-T$ condition of this rock.

Metamorphic temperature is estimated using garnet-biotite geothermometer proposed by Holdaway (2000) based on the $\mathrm{Fe}^{2+}-\mathrm{Mg}$ exchange between garnet and biotite. The pressure is estimated using garnet-biotiteplagioclase-quartz geobarometer from $\mathrm{Wu}$ et al. (2004) based on the reaction of pyrope + grossular + eastonite + quartz $=$ anorthite + phlogophite and almandine + grossular + siderophyllite + quartz $=$ anorthite + annite. High Ti content in biotite and high Ca content in garnet qualitatively indicate high temperature and pressure conditions (Holdaway, 2000). Rim of garnet with the highest grossular content and biotite with the highes $\mathrm{TiO}_{2}$ composition are selected as a pair to this geothermometry which might give a maximum temperature and pressure at peak metamorphic condition. The combination of these thermo- and barometry gives $P-T$ estimation at $562{ }^{\circ} \mathrm{C}$ and 0.97 $\mathrm{GPa}$ (Figure 5). Garnet-muscovite geother- 

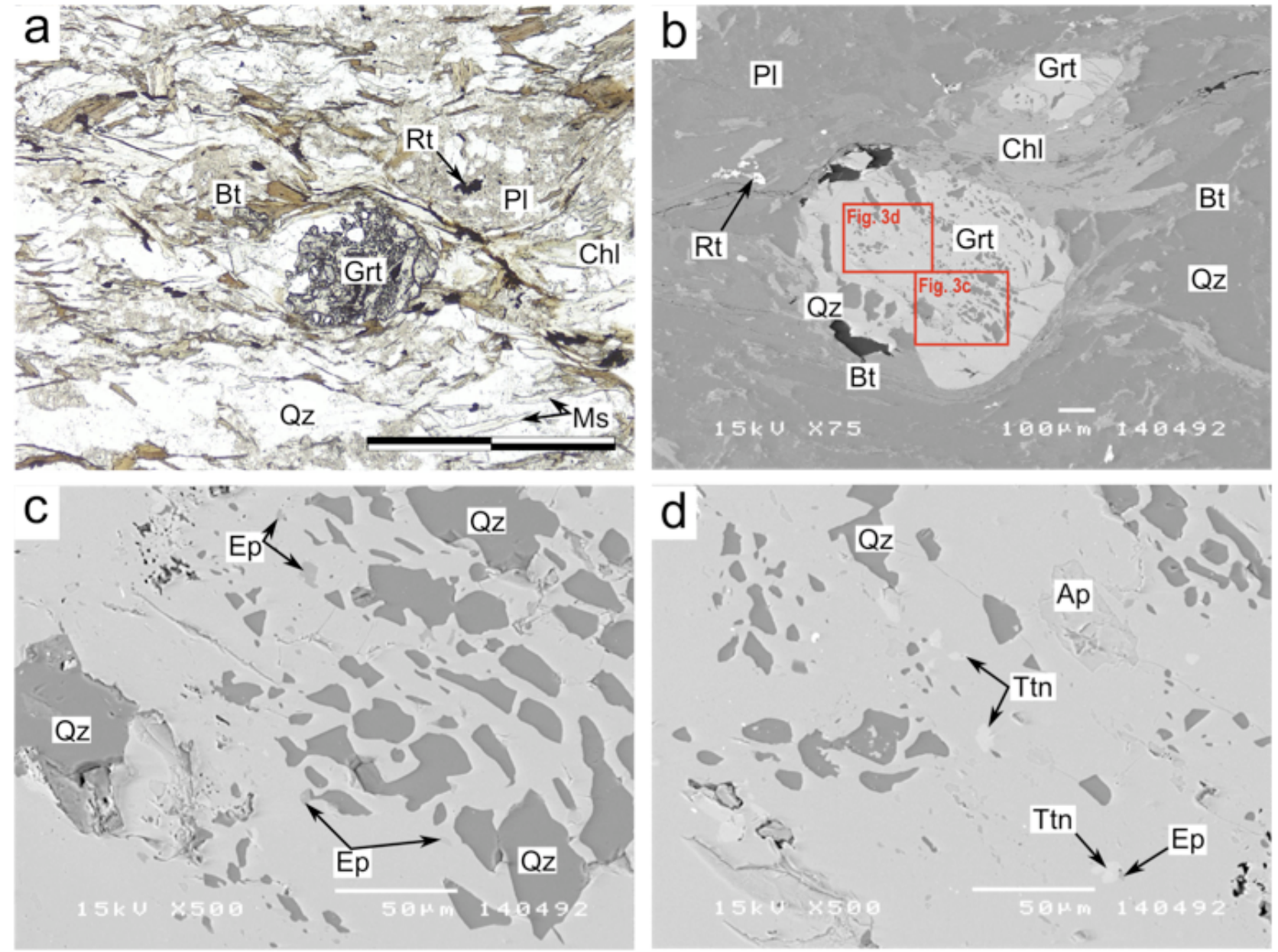

Figure 3: Photomicrograph and back-scattered electron images of garnet-biotite-muscovite schist from Barru Complex. The scale bar without expression in each of photomicrograph on this paper indicates $1 \mathrm{~mm}$. (a) The schistosity defined by biotite and muscovite. Mainly consists of garnet, plagioclase, quartz, biotite, muscovite, and rutile. Secondary chlorite is also present in this picture. (b) Porphyroblastic garnet with abundant inclusions. (c) and (d) inclusions in the garnet consists of quartz, epidote, apatite, and titanite. 

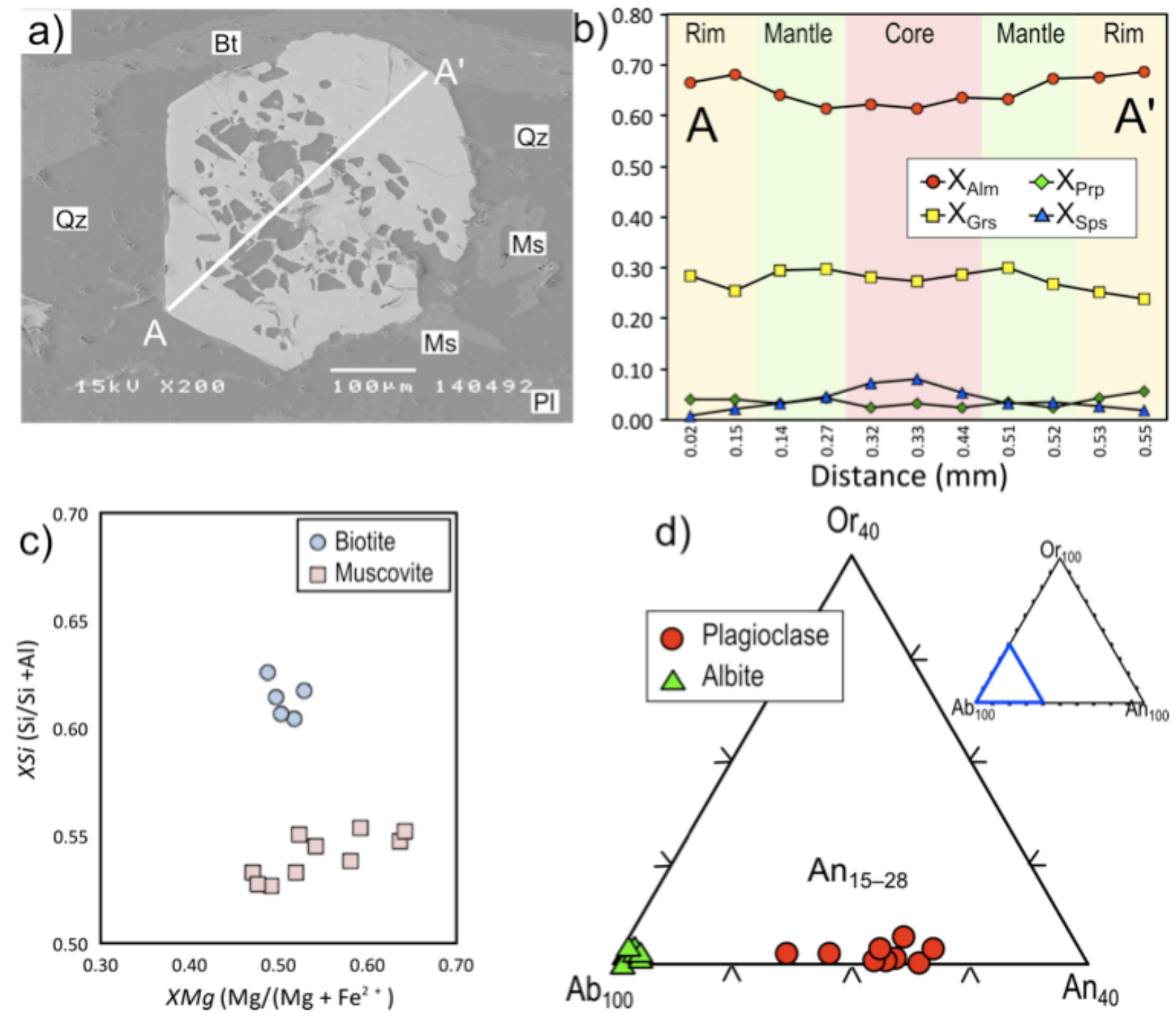

Figure 4: Representative chemical characteristic of garnet, micas, and plagioclase in garnet-biotitemuscovite schist. (a) and (b) Representative zoning profile of garnet. (c) Biotite and muscovite are distinct in $X_{\mathrm{Si}}$ component, which biotite has higher than muscovite. (d) Plagioclase in this rock has anorthite content ranges from 15 to 28 . Others are albite as secondary minerals. 
Table 2: Summary of mineral assemblages with their stage of metamorphism.

\begin{tabular}{|l|c:c:c|}
\hline P-T evolution & Prograde & Peak & Retrograde \\
\hline \hline Apatite & & & \\
Epidote & & & \\
Chlorite & $?$ & & \\
Biotite & & & \\
Garnet & & & \\
Muscovite & $?$ & & \\
Plagioclase & $?$ & & \\
Albite & & & \\
Quartz & & & \\
Rutile & & & \\
Titanite & & & \\
\hline
\end{tabular}

mometer and garnet-muscovite-plagioclasequartz geobarometer calibrated by $\mathrm{Wu}$ and Zhao (2006) have been used for comparison with the previous geothermobarometry. The Fe and $\mathrm{Mg}$ exchange between coexisting garnet and muscovite can be described as pyrope + Fe-celadonite $=$ almandine + Mg-celadonite which is the basis of garnet-muscovite thermometer ( $\mathrm{Wu}$ and $\mathrm{Zhao}, 2006)$. Whereas the equilibrium of pyrope + grossular + muscovite + quartz $=$ anorthite + Mg-celadonite and almandine + grossular + muscovite + quartz $=$ anorthite $+\mathrm{Fe}$-celadonite are used for the basis of garnet-muscovite-plagioclase-quartz geobarometer ( $\mathrm{Wu}$ and Zhao, 2006). The geothermobarometry gives $P-T$ estimation at $501{ }^{\circ} \mathrm{C}$ and $0.89 \mathrm{GPa}$, which locate lower-pressure and -temperature conditions than estimation based on garnet-biotite-plagioclase-quartz equilibrium. It suggests that these conditions can be set as minimum pressure and temperature at peak metamorphic condition of this rock (Figure 5). Hence, the peak $P-T$ conditions of the garnet-biotite-muscovite schist ranges at 501-562 ${ }^{\circ} \mathrm{C}$ and $0.89-0.97 \mathrm{GPa}$ (Figure 5).

\section{Discussion and Conclusion}

The pressure-temperature condition of garnetbiotite-muscovite schist from Barru Complex was estimated by using mineral parageneses, reaction textures, mineral chemistries, and thermodynamic data. The $P-T$ path of prograde stage passed the reaction of Ep $+\mathrm{Ttn}=\mathrm{Grt}+\mathrm{Rt}$ $+\mathrm{Qz}+\mathrm{H}_{2} \mathrm{O}$ on $1.3 \mathrm{GPa}$ at $400{ }^{\circ} \mathrm{C}$ to $0.6 \mathrm{GPa}$ at $600{ }^{\circ} \mathrm{C}$ to the peak $P-T$ condition of $501-562{ }^{\circ} \mathrm{C}$ and $0.89-0.97 \mathrm{GPa}$, which is on the stability field of garnet, biotite, muscovite, plagioclase, rutile, and quartz. The estimated peak $P-T$ conditions of garnet-biotite-muscovite schist are plotted on the field of epidote amphibolite-facies petrogenetic grid proposed by Oh and Liou (1998; Figure 5). Comparing with Bantimala Complex (30 km to the south from Barru Complex; Setiawan, 2013), the estimated peak $P$-T condition of garnet-biotite-muscovite schist shows lowpressure and medium-grade conditions but still on the ranges of estimated geothermal gradient $P-T$ path of eclogite from that complex (Figure 5). Similar geothermal gradients of metamorphisms might be indicated that these metamor- 


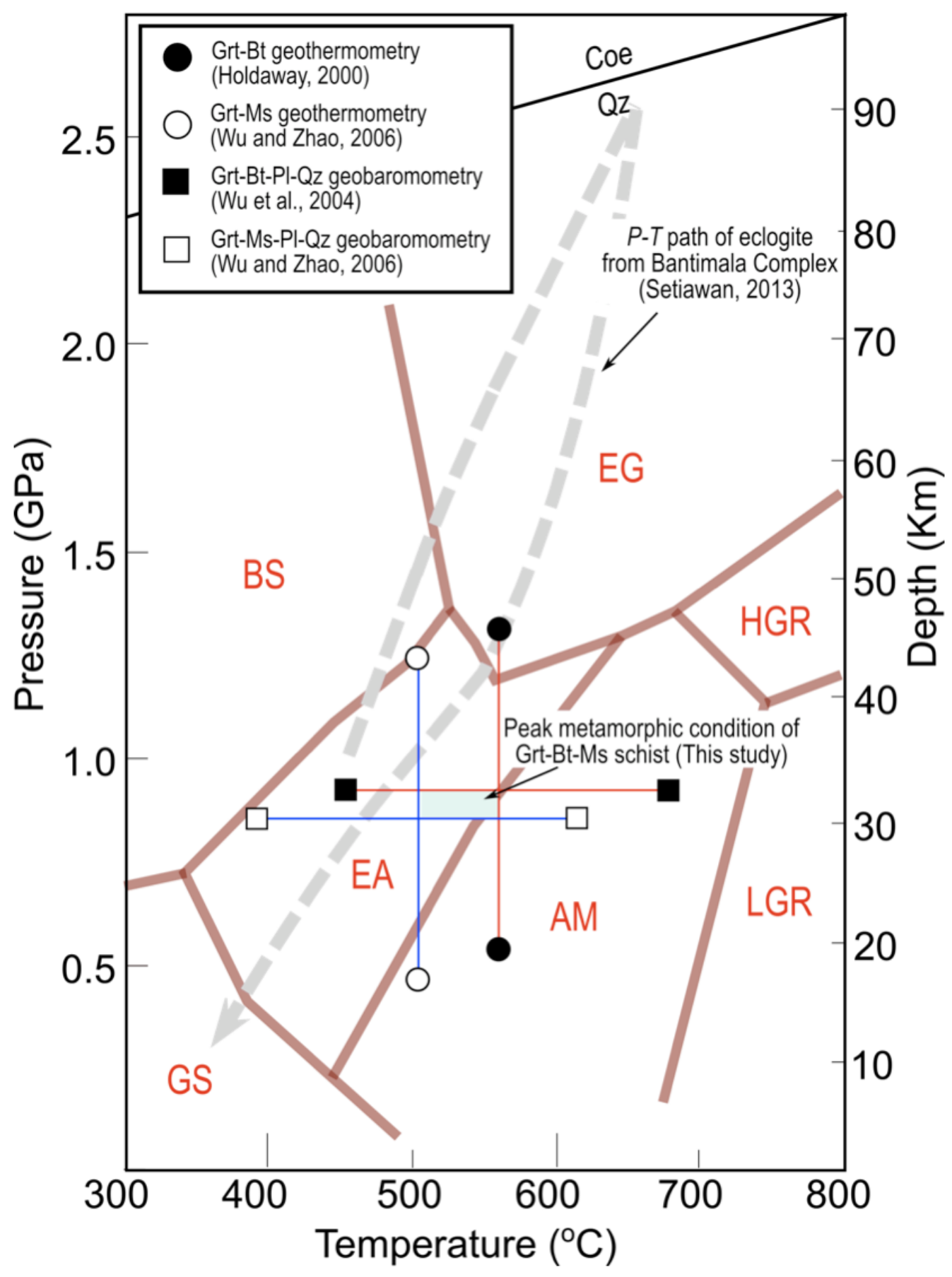

Figure 5: $P$-T estimation of garnet-biotite-muscovite schist from Barru Complex with background $P-T$ path of eclogite from Bantimala Complex (Setiawan, 2013). The petrogenetic grids from Oh and Liou (1998), the abbreviations as follows; BS: blueschist-facies, EG: eclogite-facies, EA: epidote amphibolite-facies, AM: amphibolite-facies, GS: greenschist-facies. Closed-circle is garnet-biotite geothermometry from Holdaway (2000). Open circle is garnet-muscovite geothermometry from $\mathrm{Wu}$ and Zhao (2006). Closed-square is garnet-biotite-plagioclase-quartz geobarometry from Wu et al. (2004). Open square is garnet-muscovite-plagioclase-quartz geobarometry from Wu and Zhao (2006). 
phic rocks were metamorphosed on the similar tectonic environments.

Up to now, high-pressure metabasic rocks were not reported from Barru Complex, which in contrast with Bantimala Complex $(30 \mathrm{~km}$ to the south; Setiawan, 2014). Pelitic schists and serpentinites were only metamorphic rock types founded in this area. However, K-Ar age determination on metamorphic rocks from Bantimala and Barru Complexes show synchronology data (Bantimala Complex: 137-113 Ma, Wakita et al., 1994a, 1996, Parkinson et al., 1998; Barru Complex: $106 \mathrm{Ma}$, Wakita et al., 1994a). Therefore, it is suggested during Cretaceous subduction of oceanic crust, the trenchfill turbidites, which is possibly protolith of the pelitic schist, involved into the margin of Sundaland and metamorphosed. Cenozoic tectonic activites made these main complexes separate $30 \mathrm{~km}$ in South Sulawesi and 500 to $1000 \mathrm{~km}$ with other Cretaceous accretionary complexes in Central Indonesia.

\section{Acknowledgments}

We would like to thank to staff member of Geological Engineering Hasanuddin University for their assistance during the field survey in Indonesia and for valuable discussion. This work is part of the PhD study supported by JICA AUN/SEED-Net scholarship. Fieldworks also supported by Grants-in-Aid for Scientific Research (No. 21253008 and 22244063 to Y. Osanai) from the Ministry of Education, Culture, Sports, Science and Technology, Japan.

\section{References}

Asikin, S., Handoyo, A., Busono, A. and Gafoer, S. (2007) Geological map of the Kebumen Quadrangles, Jawa. Scale 1:100,000. Geological Research and Development Centre of Indonesia.

Droop, G.T.R. (1987) A general equation for estimating $\mathrm{Fe}^{3+}$ concentrations in ferromagnesian silicates and oxides from microprobe analyses, using stoichiometric criteria. Mineralogical Magazine 51: 431-435.

Holdaway, M.J. (2000) Application of new experimental and garnet Margules data to the garnet-biotite geothermometer. American Mineralogist 85: 881-892.

Kadarusman, A. and Parkinson, C.D. (2000) Petrology and P-T evolution of garnet peridotites from central Sulawesi, Indonesia. Journal of Metamorphic Geology 18: 193-209. Kadarusman, A., Van Leeuwen, T. and SoeriaAtmadja, R. (2005) Discovery of eclogite in the Palu region, central Sulawesi, and its implication for the tectonic evolution of Sulawesi. Majalah Geologi Indonesia 20: 80-89.

Miyazaki, K., Zulkarnain, I., Sopaheluwakan, J. and Wakita, K. (1996) Pressure-temperature conditions and retrograde paths of eclogites, garnet-glaucophane rocks and schists from South Sulawesi, Indonesia. Journal of Metamorphic Geology 14: 549-563.

Miyazaki, K., Sopaheluwakan, J., Zulkarnain, I. and Wakita, K. (1998) Jadeite-quartzglaucophane rock from Karangsambung, Central java, Indonesia and its tectonic implications. The Island Arc 7: 223-230.

Oh, C.W. and Liou, J.G. (1998) A petrogenetic grid for eclogite and related facies under high-pressure metamorphism. The Island Arc 7: 36-51.

Parkinson, C.D. (1998a) The origin and emplacement of the East Sulawesi Ophiolite: Evidence from subophiolite metamorphic rocks. Journal of SE Asian Earth Sciences 16: 13-28.

Parkinson, C.D. (1998b) An outline of the petrology, structure, and age of the Pompangeo schist Complex of central Sulawesi, Indonesia. The Island Arc 7: 231-245.

Parkinson, C.D., Miyazaki, K., Wakita, K., Barber, A.J. and Carswell, A. (1998) An overview and tectonic synthesis of the pre-Tertiary very-high-pressure metamorphic and associated rocks of Java, Sulawesi and Kalimantan, Indonesia. The Island Arc 7: 184-200.

Setiawan, N.I. (2013) Metamorphic evolution of central Indonesia. PhD Thesis, Kyushu University, Japan. 318 pp.

Setiawan, N.I., Osanai, Y., Nakano, N., Adachi, T., Yonemura, K., Yoshimoto, A., Setiadji, L.D., Mamma, K. and Wahyudiono, J. (2014) Geochemical characteristics of metamorphic rocks from South Sulawesi, Central Java, and 
South-West Kalimantan in Indonesia, Asean Engineering Journal. In Press.

Sikumbang, N. and Heryanto, R. (2009) Geological map of the Banjarmasin Quadrangle, Kalimantan. Scale 1:250,000. Geological Research and Development Centre of Indonesia.

Sukamto, R. (1982) Geological map of Pangkajene and western part of Watampone Quadrangle, Sulawesi. Scale 1:250,000. Geological Research and Development Centre.

Wakita, K., Munasri, Sopaheluwakan, J., Zulkarnain, I. and Miyazaki, K. (1994a) Early Cretaceous tectonic events implied in the time-lag between the age of radiolarian chert and its metamorphic basement in the Bantimala area, South Sulawesi, Indonesia. The Island Arc 3: 90-102.

Wakita, K., Munasri and Bambang, W. (1994b) Cretaceous radiolarians from the Luk Ulo Complex in the Karangsambung area, central Java, Indonesia. Journal of SE Asian Earth Sciences 9: 29-43.

Wakita, K., Sopaheluwakan, J., Miyazaki, K., Zulkarnain, I. and Munasri (1996) Tectonic evolution of the Bantimala Complex, South Sulawesi, Indonesia. In: Hall, R., Blundell,
D.J. (Eds.). Tectonic Evolution of Southeast Asia, Geological Society of London Special Publication 106: 353-364.

Wakita, K., Miyazaki, K., Zulkarnain, I., Sopaheluwakan, J. and Sanyoto, P. (1998) Tectonic implications of new age data for the Meratus Complex of south Kalimantan, Indonesia. The Island Arc 7: 202-222.

Whitney, D.L. and Evans, B.W. (2010) Abbreviations for names of rock-forming minerals. American Mineralogist 95: 185-187.

Wilson, M.E.J. and Moss, S.J. (1999) Cenozoic palaeogeographic evolution of Sulawesi and Borneo. Palaeogegraphy, Palaeoclimotology, Palaeoecology 145: 303-337.

$\mathrm{Wu}$, C.M., Zhang, J. and Ren, L.D. (2004) Empirical garnet-biotite-plagioclase-quartz (GBPQ) geobarometry in medium- to highgrade metapelites. Journal of Petrology. 45: 1907-1921.

Wu, C.M. and Zhao, G. (2006) Recalibration of the garnet-muscovite (GM) geothermometer and the garnet-muscovite-plagioclase-quartz (GMPQ) geobarometer for metapelitic assemblages. Journal of Petrology 47: 2357-2368. 